\title{
SIDE EFFECT OF CERTAIN PESTICIDES ON THE OCCURRENCE OF THE ENTOMOPATHOGENIC FUNGI (Beauveria bassaina) AND (Meterizhium anisopliae)
}

\author{
Asmaa A. Kamel ${ }^{\text {* }}$; A.M.M. Sayed ${ }^{2}$ and S.A. Ahmed ${ }^{3}$ \\ 1. Experts sector, Minist. Justice, Abbassia, Cairo, Egypt. \\ 2. Inst. Plant Prot. Res., Cent. Agric. Research, Ismailia, Egypt. \\ 3. Dept. Plant Prod., Fac. Environ. Agric. Sci., Arish Univ., Egypt.
}

\begin{abstract}
The susceptibility of two selected fungi Beauveria bassiana and Metarhizium anisopliae was performed to certain registered pesticides. The pesticides, commonly used in the experimental area were applied at their recommend concentrations. There were singnificant difference between the tested pesteicide on the growth of $B$. bassiana and M. anisopliae. The fungicides, cosidal WP 77\% achieved the most inhibition effect to the radial growth of both fungi i.e B. Bassiana and $M$. anisopliae of 90.79 and $90.74 \%$ growth reduction, respectively. The lowest effect was recorded by each of the herbicides Stomp Extra on B. Bassiana $57.41 \%$ and the fungicide, Super Royl on M. anisopliae (49.88\%) growth reduction. From the obtained results, can recommend the pesticides that cause the lowest toxicity effect on the two entomopathogenic to use agents in integrated pest management program.
\end{abstract}

Key words: Entomopathogenic fungi, pesticides, Beauveria bassiana, Metarhizhium ansoilpae, certain pesticides, side effect.

\section{INTRODUCTION}

The use of chemicals for pest control has given rise to insecticides resistance, outbreaks of secondary pests usually held in check by natural predators, safety hazards for humans and domestic animals, contamination of ground water, and decreased biodiversity. These chemical products are becoming unacceptable for large-scale use, and increasingly there is a focus on finding alternatives for pest control, warrant for a change in control tactics to find environmentally sound alternatives for pest control. Insecticides resistance and the demand for reduced chemical inputs in agriculture have provided an impetus to the development of alternative forms of pest microbial control. Biological control offers an attractive alternative or supplement to the use of chemical pesticides (Lacey et al., 2001; Chandler et al., 2011).

The discovering, development and use of insect pathogens as classical, conservation and augmentative biological control agents have included a number of successes (Ravensberg, 2011; Glare and Moran-Diez et al., 2016). Successful microbial control system deponds on some basic principles. The establishment of such a system requires a survey of the biocontrol agent existing naturally in the insects, or in the agriculture soils followed by selecting the agents that capable to depress pest population.

An understanding of the parameters that determine the diversity and distribution of entomopathogenic species in the soil would help to identify those species best suited to a particular environment and improve

\footnotetext{
* Corresponding author: Tel.: +201287633164

E-mail address: asmaakamel_155@yahoo.com
} 
biological control efficacy. The presence of certain entomopathogens species can be considered as an indicator of their ability to survive in that environment. This information is useful for the selection of biocontrol agents because the indigenous dominant species are generally the most suitable candidates (Meyling and Eilenberg, 2007).

Fungal diseases of insects are common and widespread and contribute to the natural regulation of insect populations. Many insect pathogens (bacterial and viral pathogens of insects) must be eaten to infect their host but most fungal pathogens infect by contact and directly penetrate the insect cuticle (Inglis et al., 2001). Even though members of the mitosporic pathogenic fungi, especially Beauveria and Metarhizium strains are widely used to control whiteflies, aphids, thrips, and other insect pests in agroecosystems, only a few have been tested to control acarines (Chandler et al., 2000).

Metarhizium anisopliae is referred to as the "Green muscardine fungi" because of the green colour of its spores. Over 200 species of insects and arthropods are known to be attacked by $M$. anisopliae, and like $B$. bassiana, it has been commercially formulated e.g. Bioblast ${ }^{\circledR}$ (EcoScience Corporation, East Brunswick, NJ), Green Muscle ${ }^{\circledR} \quad$ (Becker Underwood, South Africa, Ashwood, RSA) and has been used to control a variety of insect pests such as termites, mosquitoes and other arthropods (Shah and Pell, 2003). Beauveria and Metarhizium are important entomopathogenic hyphomycetes that have been known and used widely to control a variety of pests. Each species forms about $33.9 \%$ of the mycoinsecticides produced (Meyling et al., 2009; Khain et al., 2012; Parsa et al., 2013).

We believe that insights gained from these studies will lead to the effective use of these promising microbial agents. Therefore, the present research aimed to study the side effect of certain recommended pesticides on the two popular fungi Beauveria bassiana and Metarhizium anisopliae

\section{MATERIALS AND METHODS}

\section{Chemical Used}

The following compounds were used throughout in this study at their recommend concentrations (Table 1).

\section{Toxicological Procedures}

To determine the toxicity of the tested pesticides on the two entomopathogenic fungi, $B$. bassiana and $M$. anisopliae, the technique of Pachamuthu et al. (1999) was employed. The tested pesticides were assessed in the laboratory by adding the pesticide to the growth medium of the fungi. When the growth medium of the fungi became cooled sufficiently, recommended concentration of each pesticide was added to $100 \mathrm{ml}$ of media.

The flasks containing the pesticideamended media were then hand-shaken and rolled on the clean bench to ensure the uniform mixing of pesticides with the media. Approximately $15 \mathrm{ml}$ of media amended with insecticides was poured into petri dish and allowed to solidify at room temperature under the table top horizontal laminar flow.

Approximately $1 \mathrm{~cm}$ in diameter each of fungus was placed in the centre of treated petri dish, which was then sealed with celltope. Untreated media was used as the control.

Three replicates of each treatment and control were incubated in the dark at $25 \pm$ $2{ }^{\circ} \mathrm{C}$.

The linear growth of each culture was measured, after growth of fungus completed in the control. The averages diameter of colonies $(\mathrm{cm})$ and the percentage of growth rate of each fungus to the corresponding control were calculated. 
SINAI Journal of Applied Sciences (ISSN: 2314-6079) Vol. (6) Is. (2), Aug., 2017

Table (1): The tested pesticides, their trade name, active ingredients contents and applied concentrations.

\begin{tabular}{|c|c|c|c|}
\hline Trade name & $\begin{array}{c}\text { Active } \\
\text { ingredient }\end{array}$ & Chemical name & 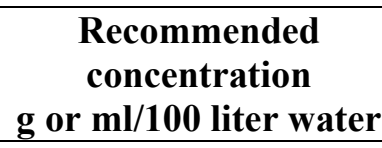 \\
\hline \multicolumn{4}{|l|}{ Acaricides } \\
\hline Abroch 5\% SC & $\begin{array}{l}\text { Fenpyroximate } \\
\quad(5 \% \mathrm{SC})\end{array}$ & $\begin{array}{l}\text { tert-butyl }(E)-4-[(1,3-\operatorname{dimethyl}-5 \\
\text { phenoxypyrazol-4yl) } \\
\text { methylenaminooxymethyl] } \\
\text { benzoate }\end{array}$ & $50 \mathrm{ml}$ \\
\hline $\begin{array}{l}\text { Abalone } 1.8 \% \\
\text { EC }\end{array}$ & $\begin{array}{l}\text { Abamectin } \\
(1.8 \% \mathrm{EC})\end{array}$ & $\begin{array}{l}\text { (1R,4S,5'S,6S,6'R,8R,12S,13S,20R } \\
, 21 \mathrm{R}, 24 \mathrm{~S})-21,22 \text {-dihydroxy-6'- } \\
\text { isopropyl-5',11,13,22-tetramethyl- } \\
\text { 2-oxo-(3,7,19- } \\
\text { trioxatetracyclo[15.6.1.14,8.020,24 } \\
\text { ]pentacosa-10,14,16,22-tetraene)- } \\
\text { 6-spiro-2'-(5',6'-dihydro-2'H- } \\
\text { pyran)-12-yl 2,6-dideoxy-4-O-(2,6- } \\
\text { dideoxy-3-O-methyl- } \alpha \text {-L-arabino- } \\
\text { hexopyranosyl)-3-O-methyl- } \alpha \text {-L- } \\
\text { arabino-hexopyranoside }\end{array}$ & $40 \mathrm{ml}$ \\
\hline \multicolumn{4}{|l|}{ Fungicides } \\
\hline $\begin{array}{l}\text { Cosidal WP } \\
77 \% \\
\end{array}$ & $\begin{array}{c}\text { Copper } \\
\text { hydroxide }\end{array}$ & $\mathrm{CU}(\mathrm{OH})_{2}$ & $406.0 \mathrm{gm}$ \\
\hline Topsin M & $\begin{array}{l}\text { Thiofanat } \\
\text { methyl } \\
(70 \% \text { WP) }\end{array}$ & $\begin{array}{c}\text { dimethyl [1,2- } \\
\text { phenylenebis(iminocarbonothioyl) }] \\
\text { bis[carbamate] }\end{array}$ & $100 \mathrm{~g}$ \\
\hline \multicolumn{4}{|l|}{ Insecticides } \\
\hline Actellic & $\begin{array}{c}\text { Pirmifos } \\
\text { methyl } \\
(50 \% \text { EC }) \\
\end{array}$ & $\begin{array}{c}\text { O-[2-(diethylamino)-6-methyl-4- } \\
\text { pyrimidinyl] O,O-dimethyl } \\
\text { phosphorothioate }\end{array}$ & $375 \mathrm{ml}$ \\
\hline $\begin{array}{l}\text { Super Royal } \\
\quad \text { oil }\end{array}$ & $\begin{array}{l}\text { Mineral oil } \\
(95 \% \mathrm{EC})\end{array}$ & O-dimethyl phosphorothioate & $1500 \mathrm{ml}$ \\
\hline \multicolumn{4}{|l|}{ Herbicides } \\
\hline $\begin{array}{l}\text { Round up } \\
48 \% \text { WSC }\end{array}$ & $\begin{array}{c}\text { Pirmifos } \\
\text { methyl } \\
(50 \% \text { EC })\end{array}$ & $\begin{array}{l}\text { O-[2-(diethylamino)-6-methyl-4- } \\
\text { pyrimidinyl] O,O-dimethyl } \\
\text { phosphorothioate }\end{array}$ & $1250 \mathrm{ml}$ \\
\hline $\begin{array}{c}\text { Stomp Extra } \\
45.5 \% \mathrm{CS}\end{array}$ & $\begin{array}{l}\text { Pendimthalin } \\
\text { (95\% EC) }\end{array}$ & $\begin{array}{l}\text { 3,4-Dimethyl-2,6-dinitro-N- } \\
\text { pentan-3-yl-aniline }\end{array}$ & $750 \mathrm{ml}$ \\
\hline \multicolumn{4}{|l|}{ Nematicides } \\
\hline $\begin{array}{l}\text { Fydate } 24 \% \\
\text { SL }\end{array}$ & Oxamyl & $\begin{array}{l}\text { Methyl 2-(dimethylamino)-N- } \\
\text { [(methylcarbamoyl)oxy]-2- } \\
\text { oxoethanimidothioate }\end{array}$ & $1500 \mathrm{ml}$ \\
\hline $\begin{array}{l}\text { Nemacap } 10 \% \\
\text { EC }\end{array}$ & Ethoprophos & $\begin{array}{c}1-(\text { ethoxy- } \\
\text { propylsulfanylphosphoryl)sulfanyl } \\
\text { propane } \\
\end{array}$ & $1250 \mathrm{ml}$ \\
\hline
\end{tabular}




\section{Data analysis}

All analysis were performed using QLMicro 2016 Excel - Stat software for statistical data processing.

\section{RESULTS AND DISCUSSION}

A number of pesticides commonly used in the areas under consideration are tested to clarify their effect on the growth of the fungi Beauveria bassiana and Metarhizium anisopliae (Table 2).

There were singnificant difference between the tested pesteicide on the growth of Beauveria bassiana $\left(\mathrm{F}_{9,89}=9.37, \mathrm{P}<\right.$ $0.001)$ and Metarhizium anisopliae $\left(\mathrm{F}_{9,89}=\right.$ 7.94, $\mathrm{P}<0.001$ ).

Results in Table 2 and illustrated in Figure 1, show that the fungicides topsin, Cosidal WP $77 \%$ acheived the most inhibition effect to the radial growth of the fungus B. Bassiana of 94.44 and $90.79 \%$ growth reduction, respectively.

The descendingly order of the other tested pesticides was the herbicide, roundup caused reduction $76.67 \%$, the insecticide actellic $68.52 \%$, nematicide fydate $67.53 \%$, nemacap $63.33 \%$, abalone $62.94 \%$, abroch, super royal oil $61.85 \%$ and $59.76 \%$ and stomp extra $57.41 \%$ growth reduction of $B$. Bassiana.

Regarding the fungus $M$. anisopliae, the highest percentage reduction in the fungal growth was achieved by each of the fungicide cosidal $90.74 \%$ and abroch as $85.19 \%$ growth reduction, followed by fungicide topsin $84.31 \%$ and insecticide abalone 82.72 . The effect of other pesticides was as follow nemacap $(72.06 \%)$, round up $(63.02 \%)$, fydate $(61.27 \%)$ and stomp extra $(57.78 \%)$ and actellic $51.36 \%$ growth reductions. The fungicide, Super Royl caused the lowest effect (49.88\%).

The results of this investigation were largely in agreement with those obtained by El-Adawy et al. (2001). It is obvious that many pesticides may be cause great damage to the microbial 1 agents. Further, the use of pesticides can lead to secondary pest problems in the field. From the obtained results, we can recommend the pesticides that cause the lowest toxicity effect on the entomopathogenic agents to use integrated pest management program.

The use of entomopathogen isolates obtained in studied regions against the economically significant pests in our country may be possible as effective biological control agents in the future.

There are great opportunities to use entomopathogens agents in biological control approaches that can improve environmental stability and, efficacy. These results could aid decision-making as to whether or not a particular cultivated or natural soil is suitable for using entomopathogens as a pest control measure and for selecting the microbial agent species best suited to a particular soil.

\section{REFERENCES}

Chandler, D.; Davidson, G.; Pell, J.K.; Ball, B.V.; Shaw, K. and Sunderland, K.D. (2000). Fungal biocontrol of Acari. Biocontrol Science and Technol., 10: 357-384.

Chandler, J.A.; Morgan, J.L.; Bhatngar, S.; Eisen, J.A. and Kopp, A. (2011). Bacterial communities of Diverse Drosophil Species: Ecological context of a Host-Microbe model System. Plos Genet., 7: 9.

El-Adawy, A.M.; El-Barogy, E.S.; Naeim, M.H.S.; Essa, M.A.A.; El-Hamawi, M.H. and Sharkawy, T.A. (2001). Factors affecting the natural occurrence of some insect biocontrol agents in cultivated soil in Ismailia Governorate. Egypt. J. Agric. Res., 79 (2): 419-430.

Glare, T.R. and Moran-Diez, M.E. (2016). What are Microbical-Based Biopesticides, Plant protection and Animal health, Agric. Plant Sci., Genet., 18:25. 
SINAI Journal of Applied Sciences (ISSN: 2314-6079) Vol. (6) Is. (2), Aug., 2017

Table (2): Effect of certain pesticides on the growth of the two isolated fungi Beauveria bassiana and Metarhizium anisopliae.

\begin{tabular}{|c|c|c|c|c|}
\hline \multirow{3}{*}{ Pesticides } & \multicolumn{4}{|c|}{ Organasim } \\
\hline & \multicolumn{2}{|c|}{ Beauveria bassiana } & \multicolumn{2}{|c|}{ Metarhizium anisopliae } \\
\hline & $\begin{array}{l}\text { Mean of radial } \\
\text { growth } \mathrm{cm} \pm \text { se }\end{array}$ & $\begin{array}{l}\text { Growth } \\
\text { reduction (\%) }\end{array}$ & $\begin{array}{l}\text { Mean of radial } \\
\text { growth } \mathrm{cm} \pm \text { se }\end{array}$ & $\begin{array}{l}\text { Growth } \\
\text { reduction(\%) }\end{array}$ \\
\hline \multicolumn{5}{|l|}{ Acaricides } \\
\hline Abroch 5\% SC & $5.38 \pm 0.07$ & 59.76 & $7.67 \pm 1.20$ & 85.19 \\
\hline Abalone 1.8\% EC & $5.66 \pm 0.33$ & 62.94 & $7.44 \pm 0.88$ & 82.72 \\
\hline \multicolumn{5}{|l|}{ Fungicides } \\
\hline Cosidal WP 77\% & $8.17 \pm 0.45$ & 90.79 & $8.17 \pm 0.44$ & 90.74 \\
\hline Topsin M & $8.50 \pm 0.38$ & 94.44 & $7.59 \pm 0.73$ & 84.31 \\
\hline \multicolumn{5}{|l|}{ Insecticides } \\
\hline Actellic & $6.17 \pm 0.67$ & 68.52 & $4.62 \pm 1.53$ & 51.36 \\
\hline Super Royal oil & $5.57 \pm 0.84$ & 61.85 & $4.49 \pm 0.13$ & 49.88 \\
\hline \multicolumn{5}{|l|}{ Herbicides } \\
\hline Round up $48 \%$ WSC & $6.90 \pm 0.95$ & 76.67 & $5.67 \pm 0.53$ & 63.02 \\
\hline Stomp Extra $45.5 \%$ CS & $5.17 \pm 0.52$ & 57.41 & $5.20 \pm 0.35$ & 57.78 \\
\hline \multicolumn{5}{|l|}{ Nematicides } \\
\hline Fydate $24 \%$ SL & $6.08 \pm 0.22$ & 67.53 & $5.51 \pm 1.00$ & 61.27 \\
\hline Nemacap 10\% EC & $5.70 \pm 0.39$ & 63.33 & $6.49 \pm 0.54$ & 72.06 \\
\hline Control & 9.00 & & 9.00 & \\
\hline LSD & 1.49 & & 1.30 & \\
\hline
\end{tabular}

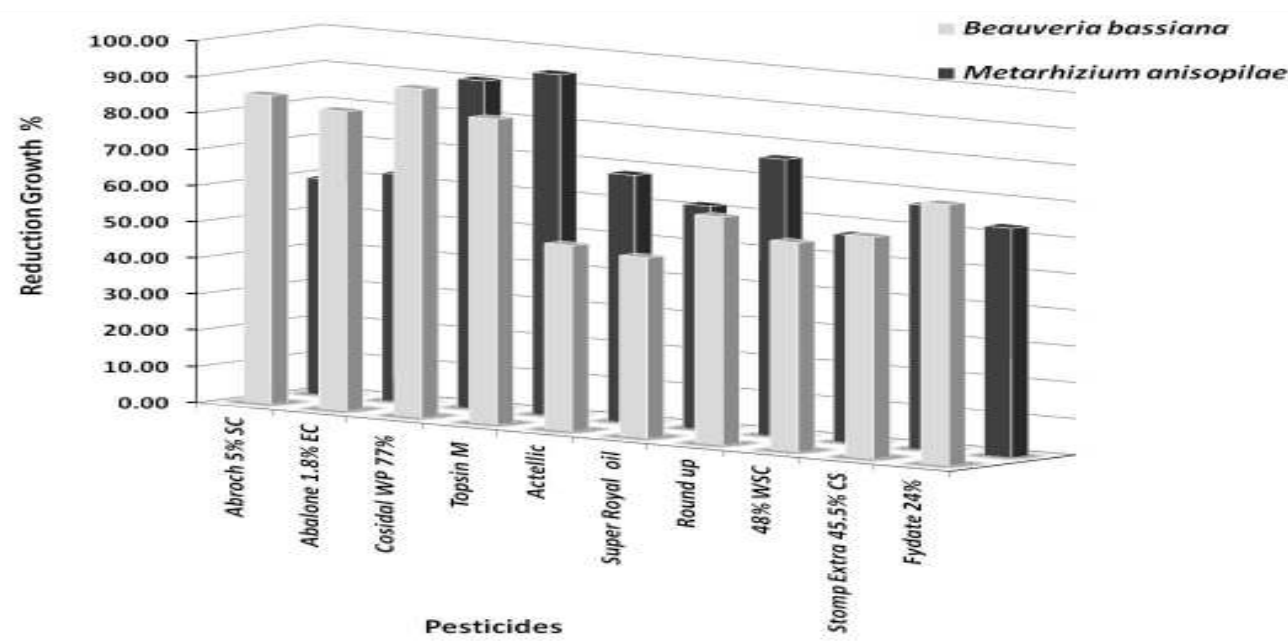

Reduction Growth (\%)

Fig. 1. Effect of different pesticides treatments on the growth of $B$. bassiana and $M$. anisopliae. 
Inglis, G.D.; Goettel, M.S.; Butt, T.M. and Strasser, H. (2001). Use of Hyphomycetous Fungi for Managing Insect pests. In Fungi as biocontrol Agents; progress, problems and potential. CABI Publishing, Wallingford, 23-69.

Lacey, L.A.; Grzywacz, D.; Shapiro-Ilan, D.I.; Frutos, R.; Brownbridge, M. and Goettel, M.S. (2015). Insect pathogens as biological control agents: do they have a future?. J. Invertebrate Pathol., 132: 1-41.

Lacey, L.A.; R. Frutos, H.K. Kaya and P. Vail (2001). Insect pathogens as biological control agents: do they have a future? Biol. Control, 21: 230-248.

Khain, S.; Gu, L.; Maimaiti, Y.; Mijit, M. and Qiu, O. (2012). Entomopathogenic fungi as microbial biocontrol agent. Molec. Plant Breed., 3: 63-79.

Meyling, N.V. and Eilenberg, J. (2007). Ecology of the entomopath-ogenic fungi Beauveria bassiana and Metarhizium ani-sopliae in temperate agroecosystems: potential for conservation biological control. Biol. Control, 43:145-155.

Meyling, N.V.; Lübeck, M.; Buckley, E.P.; Eilenberg, J. and Rehner, S.A. (2009). Community composition, host range and genetic structure of the fungal entomopathogen Beauveriain adjoining agricultural and seminatural habitats. Molec. Ecol., 18: 1282-1293.

Pachamuthu, P.; Kamble, S.T. and Yuen, G.Y. (1999). Virulence of Metarhizium anisopliae (Deuteromycotina: Hyphomycetes) strain ESC-1 to German cockroach (Dictyoptera: Blattellidae) and its compatibility with insecticides. J. Econ. Entomol., 92: 340-346

Parsa, S.; Ortiz, V. and Vega, F.E. (2013). Establishing fungal entomopathogens as endophytes: towards endophytic biological control. Visualized Experiments.

Ravensberg, W.J. (2011). Implementation of a microbial pest control product in an integrated pest management programme. In: A Roadmap to the Successful Develop. and Commercialization of Microbial Pest Control Products for Control of Arthropods. Progress in Biological Control 10, Springer, Dordrecht, 235-293.

Shah, P.A. and J.K. Pell (2003). Entomopathogenic fungi as biological control agents. Appl. Microbiol. and Biotechnol., 61: 413-423.

\section{الملخص العربى \\ التأثير الجانبي لبعض المبيدات الكيماوية الشائعة الاستخدام فى منطقه الدراسة على نمو الفطريات الممرضة الحشرات beauveria bassiana و و \\ أسماء أحمد كامل '، عاطف محمود محمد سيد"، سيد على أحمد” \\ ا ـ - مصلحة الخبراء، وزارة العدل، مصر.

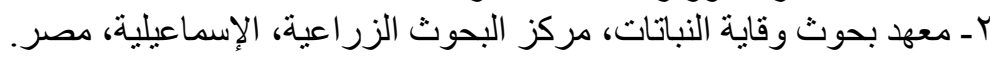

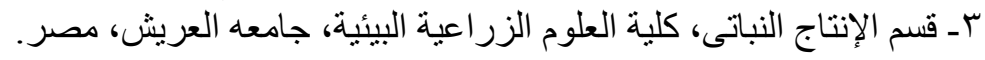

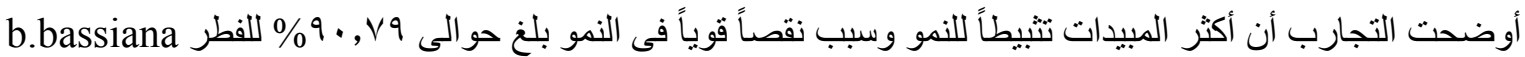

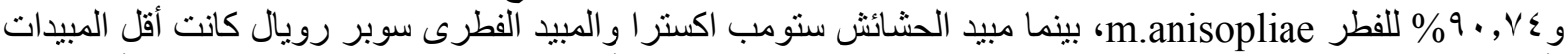

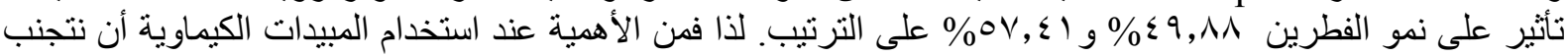

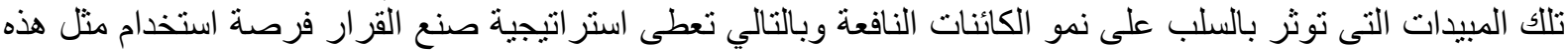
المسببات الممرضة للحشر ات كعو امل مكافحة فعالة فى برنامج المكافحة المتكاملة للآفات.

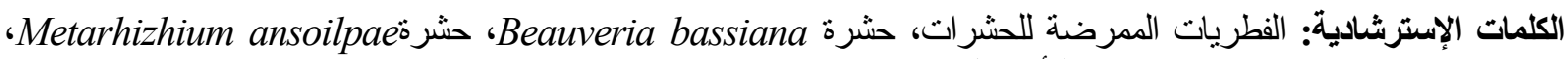

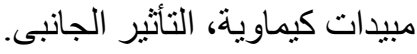

أستاذ الحشر ات الاقتصادية، كلية العلوم الزر اعية البيئية، جامعة العريش، مصر .

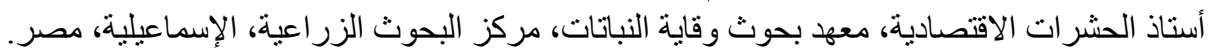

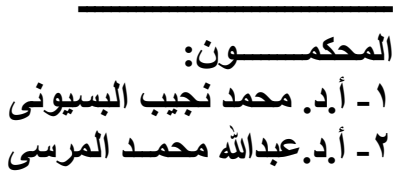

